\title{
The Disappointed and Disgruntled: A Study of the Return in the 1990s of Czech Emigrants from the Communist Era*
}

\author{
ZDENĚKK R. NEŠPOR** \\ Institute of Sociology, Academy of Sciences of the Czech Republic, Prague
}

\begin{abstract}
Any in-depth research on Czech emigration to the West in the communist era, and on the return of these emigrants in the 1990s, has until now been almost nonexistent, although it could provide a deeper comprehension of present Czech society and its cultural values. The article provides a strong theoretical basis for this kind of study, which starts out from P. Berger's and T. Luckmann's theory of socialisation, and compares it with the socio-economic point of view, considered the most useful research method for this particular field. After a brief description of former developments, the article concentrates on a more detailed analysis of the recent process of the emigrants' return, which is described on the basis of qualitative biographical research. The author attempts to explain why the emigrants decided to return, including the factors of their prosperity abroad and their attitudes to modern capitalism and analyses the process of their (re-)integration into Czech society. The main conclusion is that economic and work characteristics have played the most important role in the decision, although some other factors (especially time) must also be taken into account. The emigrants who have returned to the Czech Republic have found above-average employment positions in the country. However, their social adaptation contrasts sharply with this prosperity, partly owing to the envy of other people, and partly as a result of the significant difference in attitudes towards individual-collective relations.
\end{abstract}

Sociologický časopis/Czech Sociological Review, 2002, Vol. 38, No. 6: 789-808

In the light of Schütz's famous analogy of the sociologist as stranger [1944; see also 1945], it is clear that an important research field of qualitative sociology must be emigration studies. Regardless of contingent general agreement with the analogy, emigrants and those who return after emigrating, or re-emigrants, have special personal experience with two different social identities, two culturally settled value frameworks, and even two symbolic universes. They recall the cultural values and social roles of the former homeland society, but they must also adapt to new values and roles in a relatively short period of time. A differ-

\footnotetext{
* This research was supported by the internal grant no. Z7028912-2002 'Reemigrace zahraničních Čechů, především emigrantů z vyspělých zemí, do ČR v 90. letech 20. století' [Re-emigration of Czechs from Abroad, Especially Emigrants from Advanced Countries, to the Czech Republic in the 1990s] from the Academy of Sciences of the Czech Republic. The funding is gratefully acknowledged.

** Direct all correspondence to: Zdeněk R. Nešpor, Institute of Sociology, Academy of Sciences of the Czech Republic, Jilská 1, 11000 Prague 1, e-mail: nespor@soc.cas.cz
} 
ence in values, or even a struggle between two identities, is inevitable in this situation; the only solution is in the careful and usually rational evaluation and daily re-thinking of the cultural value basis. It is this rational understanding of the fundamental elements of culture, or at least the struggle towards it, that the emigrants are able to provide us with.

An historical opportunity is presented in the fact that the political and economic transformation of the Czech Republic after November 1989 has led to the return of many Czechs who used to live abroad. ${ }^{1}$ A major specificity that contrasts with the experience of practically all other post-communist countries is that the migration flow from Western countries to the Czech Republic (and also Slovenia) in the 1990s is stronger than the flow in the other direction [see below; Hoenekopp 2000: 7-10]. This strong migration flow has in part been comprised of Westerners who have decided to live (mostly temporarily) in the Czech lands, but the majority is constituted by re-emigrants, i.e. people with double emigration experience in the mentioned sense. ${ }^{2}$

There are two main social groups of emigrant Czechs who have been part of the reemigration process in the 1990s. The first group - about ten times smaller than the second but already the subject of study ${ }^{3}$ - was comprised of Czechs from Romania and the former USSR, who had been unable to leave the location they were living in during the state-backed re-emigration that took place after the Second World War. The second group, one much larger but thus far almost entirely neglected by sociologists and anthropologists (with the exception of marginal references to the subject in two works: [Hrubý - Brouček 2000; Brouček et al. 2001]), is formed of Czechs who left Czechoslovakia during the communist era (1948-1989) and their descendants. There are some important differences between these two groups. Although only a certain part of the first type of re-emigration was backed by the state, it usually had a deep social basis and reflected the institutional structures of the emigrant groups. In contrast, the second type has been strictly individual in character. Another important difference lies in the fact that in the former case the re-emigration process affected all (or almost all) members of the Czech enclaves abroad, while in the latter case it has involved only a small minority. The research in this paper is dedicated to the second group.

\section{A theoretical basis}

When studying any kind of (re-)emigration process one must take into account the fact of societal change and the consequent shift in values among those involved; that is, one must study not only the specific causes and reasons for emigration (which often are, unfortunately, only postulated), but also and especially the personal value shifts that have oc-

\footnotetext{
${ }^{1}$ In Czech, the process is usually called 're-emigration'; I use the term of 're-emigrant' as a synonymum to a returnee.

${ }^{2}$ It seems to be true that this difference between the Czech Republic and all other post-communist countries is of a qualitative nature, and not only numerical, but this assumption must be sustained by wider comparative research in the future.

${ }^{3}$ See, for example, [Češi 1992; Secká 1993, 1996; Nešpor et al. 1999-2002].
} 
curred and which are inevitable during the process. This general rule is of special importance in this case owing to the fact that the great majority of Czech re-emigrants of the 1990s have experienced two different value shifts - first during their emigration to the West, and second during their return to a Czech society which had changed during their absence, but which had also become idealised in their eyes.

\subsection{Institutional areas of study}

It is only theoretically possible to conduct any 'absolute' in-depth analysis of the differences in terms of cultural values and symbols between the homeland society and the society of the 'host' country, and between the idealised image of the homeland and current reality. Therefore, it is important to uncover the specific symbolic and institutional areas of value differences (eo ipso of later value shifts) relevant to the study, while others must be considered as only related or of no importance. I have identified certain areas of political and civic behaviour and economic and work relations that are the most important institutional spheres, and there are three reasons that led to their being designated as such.

First, in the selected spheres there existed a fundamental value and ideological difference between the Western and the so-called socialist societies, which has also affected all their related aspects (e.g. gender relations, job structures). Second, this very difference led to the subjective motivations for emigration and ipso facto created its most important value frame. Other differences, including family and kin relations, although not entirely marginal, played only a secondary role, except in the area of work and economic relations (i.e. 'kin jobs', the help of family and friends in the search for employment and in entrepreneurial activities, art as an area of employment in the case of artists etc.). Finally, the process of the political, economic, and social transformation of the Czech Republic after 1989 is the process in which the economic transition has been (at least rhetorically) favoured for so long that it modified and/or eliminated structural shifts in other areas.

For these reasons the re-emigrants to the Czech Republic, who are to some extent the bearers of three different cultural identities, are also able to provide deeper insight into the transition process and its prospective success. An evaluation of this kind must be rooted not only in common Czech social norms and values, but also in the past development of these norms and values, and in the mentality, norms, and values of the former host society. The study must concentrate primarily on the reciprocal influence of the economic, social, political, and legal spheres, including informal, semi-legal and illegal practices (the new business elite, networks, reciprocity, corruption etc.), and should focus on analysing personal values, which are the main motivation factors in social behaviour (including, for example, prejudices and attitudes to public and civic spheres, and their impact on work flexibility, risk-taking, creativity, competitiveness, self-reliance etc.).

Given the fundamental role of the economic and employment spheres, the subjective measure of prosperity ${ }^{4}$ should be set as a key classification aspect. This prosperi-

\footnotetext{
${ }^{4}$ It is possible to set an objective measure of economic and work prosperity. However, this would be counterproductive due to the relative lack of data and to the fact the (re-)emigration is always
} 
ty $(u)^{5}$ can be defined as the outcome of the mutual interaction of subjective personal economic and work factors and social and environmental factors, for which not only the difference from the postulated mean prosperity is important, but also the difference from the idealised maximum expected personal prosperity is of primary significance, regardless of the social, political, and economic context. In the case of subjective prosperity in socialist Czechoslovakia, two ideal contingencies of eventual emigration could be observed:

1. Achieved prosperity was higher than or equal to the maximum expected level $\left(u_{a} \geq i_{a}\right)$ and had an anti-emigration influence; or

2. Achieved prosperity was less than the maximum expected level $\left(\mathrm{u}_{\mathrm{a}}<\mathrm{i}_{\mathrm{a}}\right)$, which in certain cases was a pro-emigrational factor.

If the subject did then emigrate, his/her ensuing economic and employment development directed him/her into two other contingencies:

2a. Achieved prosperity was higher than or equal to the expected level $\left(u_{b} \geq i_{b}\right)$, which led to self-satisfaction and the wish to stay in the host society; or

$2 b$. Achieved prosperity was less than expected $\left(\mathrm{u}_{\mathrm{b}}<\mathrm{i}_{\mathrm{b}}\right)$, which led to a yearning for change, either through a second migration or by returning to the homeland. ${ }^{6}$

With respect to the subjects' attitudes to potential re-emigration after 1989, and to the important social, political, and economic transformation within the homeland, the following consequences were observed: ${ }^{7}$

In the case of contingency $2 \mathrm{a}$ :

1. The subject decided to remain in emigration; or

2. The subject decided to re-emigrate

a. owing to reasons outside the sphere of the subject's economic and employment situation; or

b. owing to an expected increase in earnings in the economic and work spheres, or its equality in case of an earnings increase in other cultural spheres $\left(\mathrm{i}_{\mathrm{a} 1} \geq \mathrm{u}_{\mathrm{b}}\right)$.

voluntary, i.e. depends on the subjective assessment of prosperity. Conversely, it is important to say first that this assessment was not the only motivation factor in migration decisions, and second, its sociological and anthropological study must not proceed only from its 'emic' definition, but also from the 'ethic' evaluation, mediated by some kind of a 'thick description'; it is clear that later personal evaluations of one's own behaviour are quite different from the temporal ones.

${ }^{5}$ Index ' $a$ ' is used for the homeland society in the time of emigration, while 'a1' for the time of reemigration, and ' $\mathrm{b}$ ' for a host society, whose temporal change was ipso facto not visible to the participants (that is why I do not use index 'b1').

${ }^{6}$ The same factors $\left(\mathrm{u}_{\mathrm{a} 1}\right.$ and $\mathrm{i}_{\mathrm{a} 1}$ relation) were (later) applied in the post-return adaptation to Czech society; this situation is clear enough so I will not schematise it extensively.

${ }^{7}$ This typology is made only on an idealised assumption of economic-work sphere domination; it takes no account of other important motivation factors (e.g. age of subject, kin relations, friendships, religious and some special-interest groups etc.). 
Table 1. A typology of emigrants' attitudes to re-emigration according to the theory of social values and a socio-economic model - a comparison (stylisation)

\begin{tabular}{|l|c|c|c|c|c|}
\hline & $2 \mathrm{a} .1$ & $2 \mathrm{a} .2 .1$ & $2 \mathrm{a} .2 .2$ & $2 \mathrm{~b} .1$ & $2 \mathrm{~b} .2$ \\
\hline $\mathrm{Ia}$ & ++ & -- & -- & ++ & - \\
\hline $\mathrm{Ib}$ & - & + & + & -- & ++ \\
\hline $\mathrm{Ic}$ & - & ++ & + & - & ++ \\
\hline $\mathrm{IIa}$ & -- & + & + & -- & ++ \\
\hline $\mathrm{IIb}$ & ++ & -- & -- & ++ & - \\
\hline
\end{tabular}

Occurence: ++ high probability; + possible; - low probability; - impossible.

In the case of contingency $2 \mathrm{~b}$ :

1. The subject decided to remain in emigration owing to reasons outside the sphere of the subject's economic and employment situation; or

2. The subject decided to re-emigrate, primarily owing to an expected earnings increase in the economic and work spheres, or its equality in case of an earnings increase in other cultural spheres $\left(\mathrm{i}_{\mathrm{a} 1} \geq \mathrm{u}_{\mathrm{b}}\right)$.

Both in the cases of re-emigration (2a.2.a and b; 2b.2) and in the cases of remaining in emigration $(2 \mathrm{a} .1 ; 2 \mathrm{~b} .1)$ it is possible to compare the voluntary decisions the subjects have made in this respect with a measure of the degree to which they had become integrated in the host society: ${ }^{8}$

I. The subject has been re-socialised and his/her personal identity has altered in the host society, which has led to the assumption of an attitude comparable to that of the so-called 'God's grandchildren', as conceptualised in the social psychology of religions [Holm 1998: 138-139]. The subject will then:

I.a. deeply identify him/herself with a new identity (of the host country), and resist any temptation to re-emigrate; or

I.b. attempt to live on the borderline between the old (Czech) and the new (host country) identities, but without any subjective satisfaction; or

I.c. fully resume the old (Czech) identity, which has obviously become idealised.

II. The identity of the subject has only partially changed in the host society in the process of secondary socialisation (which means the new social values and roles exist only in relation to the old ones), which has led to a comparison of the symbolic universes and value frameworks of both societies. The subject will then:

II.a. re-emigrate, i.e. accept the old (Czech) social values and roles, but with strong signs of having been integrated into the host society; or

\footnotetext{
${ }^{8}$ In this description I follow P. Berger's and T. Luckman's conception of socialisation [1966: chap. 3.1.) although with a certain shift: the authors defined the secondary socialisation just as an internalisation of institutionalised particular symbolic universes on the basis of the division of labour, while I use the term for any 'Überbau' of primary socialisation.
} 
II.b. refuse to return, i.e. remain in the new society, with its values, but with strong signs of having been previously socialised in the Czech society.

At this point it is possible to present a comparison of the possible consequences of both theoretical conceptions of re-emigration and subjective motivations (see Table 1).

\subsection{Typology of re-emigrants}

Out of this typology of motivation factors for eventual re-emigration, which is based on socio-economics and the theory of social values, the following possible (ideal) types of emigrant behaviour in relation to re-emigration can be defined:

The radical new-settler is a person who has come to fully identify with the host society, who has been re-socialised there and has fully accepted the new cultural values. The new-settler has completely forgotten (or at least has tried to) his/her 'former homeland' and his/her evaluation of the new society is 'holier than Thou' in character. This type of emigrant rejects any prospective return regardless of personal, economic and work success; in some rather exceptional cases re-emigration may occur, but only for economic reasons (pressure from an employer, strong positive incentives, i.e. property restitution etc.).

The uncertain fluctuant is a person who has been re-socialised in the host society, but owing to structural changes in the homeland, the outcome of this process has been weakened in favour of the former (usually idealised) identity. This situation has led to strong internal pressure, which the emigrant tries to deal with either in one of the two societies or through a fast switch between the two societies, but with no real consciousness of any subjective satisfaction. In the case of economic success in the host society, the possibilities of staying or returning are almost equal, although returning is slightly more probable owing to a strong sense of self-confidence on the part of this person; in the other case re-emigration is also highly probable.

The radical patriot is a person who has been re-socialised into the host society, but structural changes in the homeland have radically negated the results of the process. The person maintains an idealised view of the old-and-new homeland and tries to 'help' it as much as possible, though this sometimes leads to a value clash with the majority of the homeland population. In the case of economic success in the host country, re-emigration is highly probable (its motivation factors lie in areas outside the sphere of economics, though re-emigration is inevitably connected with a struggle for the valorisation of property of foreign origin, including human property), as in the other case, although in this situation re-emigration should be a shield from feelings of personal faults.

The diligent re-emigrant is a person who has been secondarily socialised (but not resocialised) in the host society, and who has always compared the cultural values of both societies. Consequently, this person is regarded as being discontented and is viewed as a complainer by his/her neighbours. The diligent re-emigrant returns ex definitione, regardless of how successful he or she has been in the host country; this type is nonetheless more common among emigrants who are dissatisfied economically and in terms of work. How- 
ever, their socialisation into Czech society is not easy owing to their reserved character and even shyness.

The diligent immigrant is just the opposite of the previous type. Neighbours in the host society regard this person purely as an immigrant and unable to integrate into the society, even though to some extent s/he does try. The second generation of the diligent immigrants usually no longer have such problems and are fully socialised in the 'new' society. Emigrants of this type do not return to the 'old homeland', and if in exceptional cases they do, it is for economic reasons (as in the case of the radical new-settlers).

\section{Research methodology}

The value attitudes of Czech, Western re-emigrants of the 1990s, and the influence of these attitudes on their social behaviour, are the subject of a qualitative sociological study that began in April 2002 within the framework of a research programme of the Department of Economic Sociology of the Institute of Sociology of the Czech Academy of Sciences. The following parts of this paper present the first results of the research.

\subsection{Research methods}

The theoretical and methodological background of the research lies primarily in economic sociology, social anthropology, and the sociology of knowledge. The essential research method is a combination of historical, biographical, sociological, and anthropological analysis, i.e. a qualitative analysis of subjective biographical narratives and other relevant data sources, in order to better understand the 'value background' of Czech re-emigration and its developments at the end of the 20th century.

\subsection{Data acquisition}

For the purpose of acquiring data two main techniques were used: open (non-standardised) in-depth interviews, and written-source analysis. The latter proceeds from an analysis of many published and unpublished autobiographical works of emigrants or re-emigrants, including their attempts at making a professional historical and sociological analysis. As the authors themselves have been much affected by a change in values as a consequence of their migration, their analysis is obviously biased. The studies of Pavel Tigrid [1990] and Jan Filípek [1999], although among the most valuable examples of such sources, are good examples of this point, as are other works, for instance, by the historian Bořivoj Čelovský, the singers Jaroslav Hutka and Karel Kryl, the physicist František Janouch, the reverend (and new MP) Svatopluk Karásek, the publicist Jožka Pejskar, the anthropologists Ladislav Holý and Petr Skalník, the physician Karel Steinbach, the economist and politician Ota Šik, and others.

Written sources, along with the interviews, which I will discuss further on, are used 
to provide biographical data and statements on six main topics: (1) emigration analysis the timing of emigration, its contextual and biographical situation, subjective motivation and aims, the course it took in reality, economic assets, work, qualification assets, social integration into the host society etc.; (2) re-emigration analysis - the same questions, but applied to re-emigration, the subjective assessment of relations to the society and vice versa, and the means of (re-)socialisation, including the influence of different social groups etc.; (3) analysis of the subjective evaluation of Czech society - the persistence of communist power structures and social mechanisms, new elites, lobbies, social networks and how they work in all kinds of institutional spheres, political and civic involvement of the societal majority, the relation between business and politics etc.; (4) analysis of personal development in economic and work areas - changes in these areas during and due to migrations, social networks, the subjective evaluation of the Czech social environment (area of work, ways of working, responsibility, risk-taking, creativity, mobility, flexibility, self-exploitation, corruption and other illegal practices, the validity of informal agreements, interpersonal relations, attitudes to money, wealth, voluntary activities etc); (5) analysis of kin and social relations - including their value background, and the questions of raising children and education; (6) general information - a subjective characterisation according to ascribed and acquired qualities, the verification of data through a comparison of statements and crossquestion analysis etc.

\subsection{The construction of the research group}

The most important method of data acquisition is the open (non-standardised) in-depth interview conducted with the re-emigrants. However, the construction of the group to be studied is complicated for several reasons. There is no (available) central register of re-emigrants, and the emigrants in general harbour suspicions towards the police and the state. Another problem is the relative heterogeneity of the population of re-emigrants, and their dispersion throughout the Czech Republic (although Prague hosts most of them; HrubýBrouček 2000: 28]. For these reasons I have used the snowball technique of research group construction, and occasionally also a purposeful selection of firms which typically employ re-emigrants.

The validity and reliability of the research lies in the sufficiently heterogeneous nature of the population; Western re-emigrants do not form large groups (each of them has usually only two or three friends with similar experiences), while they usually know more re-emigrants (but not friends) on other grounds (former schoolmates and peers, people with similar special interests, co-workers etc.). For this reason, the sampling has no systematic error. In addition, the response rate so far has been 100 per cent.

An extension of the field is planned for the near future, which will also include the majority of emigrants - i.e. those who refused to return to the Czech Republic in the 1990s, or returned, but later left again (usually to their former host societies) - and a reference group of the re-emigrants' neighbours, co-workers, friends, relatives etc. 


\section{Historical and social backgrounds}

The Czech lands have experienced many political, religious, and economic migration waves from the end of the Middle Ages up to the present time. These have included the emigration of the Czech non-Catholics during the period of re-catholicisation, the immigration of Germans up until the 18th century, Czech economic emigration to the USA and some other countries in the late 19th and early 20th centuries, and other migration waves. Generally speaking, Czech emigrants usually settled successfully in the host countries and after a time, usually with the second generation, they lost their relationship to their homeland country and their relatives. However, some of the emigrants came to constitute ethnically based groups and social structures in the host countries; groups which endured over time and occasionally played an important role in the relationship to Czech society and to later emigrants.

\subsection{Former Czech emigration and its relationship to emigrants of the communist era}

The lands that comprise the Czech Republic today produced in the past, like other European countries in the late 19th and the early 20th century, large emigration waves that moved in the direction of the United States and other countries, motivated by the public perception of there being greater opportunities for personal development elsewhere. Although Czech emigrants formed strong social networks and organisations based on ethnicity, religion, work, and special interests in the period before 1939 [Chada 1981; Filipek 1999], these organisations operated only on an institutional, 'folkloric' basis. The relations between the relatively strong Czech community in the USA and the homeland were quite poor, as were the genuine, reciprocal ties within the group owing to the more or less wholesale adoption of the social and cultural norms of the host country. Their ' $\mathrm{Czech}$ national awareness' played only a marginal role. For this reason, the great majority of the Westernbased Czechs, in contrast to the ones based in Eastern Europe [Češi 1992: 52], rejected the re-emigration calls that went out at the end of both world wars. When they wanted to help the old homeland, they did so by providing some professional advice or through financial support. In fact, they felt themselves to be primarily American or French etc., and not as members of a 'great Czech nation', in L. Holý's [1996] sense.

Given the fact that the first emigrants during the communist era, i.e. politicians, businessmen and civil servants, fled the country because of the political changes and usually expected an early change in the political map of Europe, their relationships to the emigrants who had preceded them (and who had 'betrayed the nation' through their lack of interest) were quite poor and/or even hostile.

\subsection{The extent and structure of communist era emigration}

Emigrants during the communist era wanted to escape communism for a number of different reasons; politicians and public officials feared the possibility of being persecuted, as 
did businessmen, who in addition were unable to engage in entrepreneurial activities. All the emigrants had a strong sense of a lack of opportunities for personal and professional progress. On the other hand, there were important differences among them, which led to the deep fragmentation of the Czech emigrant community and to the above-mentioned mutual hostility.

Pavel Tigrid [1990: 55, 92] and other authors divided this emigration into two different waves; the first one was the so-called 'February 1948 emigration', which started just after the communist take-over and continued up until the Prague Spring of 1968. This migration wave resulted from strong opposition to the communists, whereas the next wave, the 'August 1968 emigration' was to a large extent comprised of the former Communist Party members or regime supporters of the 1950s and 1960s. Members of the latter emigration wave, which continued up until 1989, were either communist reformers who became the object of persecutions in the 'normalisation' period, or professionals who felt discriminated against by the communist personal and professional politics and who expected positive personal, social, and financial progress in the West. The last type of emigrants can be considered to be economic migrants, quite similar to those who had migrated much earlier in the pre-war period [Filípek 1999: 23]. In conjunction with the need for help among the August 1968 emigrants, this similarity led to the formation of positive relations among the members of these two groups, and to their opposition to earlier post-war emigrants [ibid.: 23; Tigrid 1990: 102-103].

The size of the February 1948 emigration wave is usually estimated at about 60000 people [Tigrid 1990: 43; Filípek 1990: 13], while the August 1968 emigration was two or three times larger. It could include from 100000 [Tigrid 1990: 92] to some 200000 people [Hrubý-Brouček 2000: 27]. There are also important differences between the selected host countries: the earlier groups of emigrants wanted to go to the USA, and after some peripeteias the majority of them indeed succeeded in doing so [Filípek 1999: 20, 56], whereas the August 1968 emigrants usually stayed in Western Europe. The USA, Australia, and other overseas destinations became popular (or, due to immigration laws, in some cases the only possibility) again in the 1980s.

In general, one may also see the distinction between the two later emigration waves in the opinions emigrants had about integration into the host societies. The February 1948 migrants formed certain political and civic organisations in the host societies aimed at maintaining Czech national feeling, which were similar but until the 1960s usually parallel to (i.e. separate from) the organisations of their pre-war fellow-countrymen in the host society. However, these social groups did not constitute any kind of ethnic economy [Light-Karegeorgis 1994], they functioned only as structures for the preservation of folklore. The work, economic, social, cultural, and political values of the Czech February 1948 emigrants became 'Americanised' in a relatively short time - usually by the second generation - so that their 'Czech origins' served merely as a thin label of sentimental memories, in some circles adjusted by a deliberate cultivation of archaic rituals and the Czech language, along with a nostalgic longing for the revival of the Czech pre-war democracy. But such circles, usually connected with political parties in exile, were in fact quite marginal. 
Whereas the post-war emigration did not want to assimilate but in fact had to do so, the majority of the August 1968 migrants represented a different case. They usually wished for a rapid integration into the host societies, even though in some cases they also formed Czech emigrant groups or joined the existing ones. These organisations and informal social networks helped them fundamentally in the sphere of work, while most of them lost any interest in developments in Czechoslovakia and worked only on their own social integration [Brouček et al. 2001: 34-35].

\subsection{Possibilities for re-emigration}

A small number of Czech emigrants decided to return to communist Czechoslovakia even before 1989, usually due to a combination of homesickness and personal economic and employment failure in the West. Their fate was usually bad, and although many of them took advantage of presidential amnesties to move back, some were imprisoned immediately [Koudelka et al. 1993: 20], while others were forced to make humiliating self-

Table 2. Immigration to Czechoslovakia (until 1992) and the Czech Republic from selected countries

\begin{tabular}{|l|r|r|}
\hline Country of origin & persons & per cent \\
\hline Australia & 1657 & 4.7 \\
\hline Austria & 2491 & 7.1 \\
\hline Belgium & 287 & 0.8 \\
\hline Brazil & 18 & 0.1 \\
\hline Canada & 3598 & 10.2 \\
\hline Denmark & 98 & 0.3 \\
\hline Finland & 28 & 0.1 \\
\hline France & 722 & 2.0 \\
\hline Germany* & 14043 & 40.0 \\
\hline Greece & 887 & 2.5 \\
\hline Italy & 1370 & 3.9 \\
\hline Izrael & 130 & 0.4 \\
\hline Netherlands & 536 & 1.0 \\
\hline Norway & 52 & 0.2 \\
\hline South Africa & 254 & 0.7 \\
\hline Spain & 130 & 0.4 \\
\hline Sweden & 727 & 2.1 \\
\hline Switzerland & 2992 & 8.5 \\
\hline UK & 1184 & 3.4 \\
\hline USA & 3959 & 11.3 \\
\hline Total & 35144 & 100 \\
\hline
\end{tabular}

Source: Czech Statistical Yearbooks 1991-2001, author's calculation.

* Until 1990 without former East Germany. 
critical declarations and to ideologically condemn emigrants [Filipek 1999: 81-83]. It is consequently of no surprise that the number of those who followed them back was very small.

But even after 1989 only a small portion of the emigrants have returned to the Czech Republic. No exact figures on the number of re-emigrants are available; estimations can only be based on some statistical data relating to international migrations (see Table 2). There were at least 35000 immigrants to the Czech Republic from the West in the period of 1989-2000, over 75 per cent of whom were from Austria, Canada, Germany, Switzerland, and the USA (the countries with the highest numbers of Czech emigrants). It is commonly assumed that the majority of the immigrants were re-emigrants [Hoenekopp 2000: 7]. But even if all these immigrants were re-emigrants, this is still only a small part (13-22 per cent according to different estimations) of the total number of emigrants from the communist era. In most cases the emigrants had already become assimilated into the Western societies, and thus usually did not want to disrupt their personal, family, economic, and work relations in the new society [Filípek 1999: 134; Hrubý - Brouček 2000: 104]. ${ }^{9}$

One can also clearly understand that re-emigration is much more attractive or even possible for relatively recent migrants than for the large majority of the post-February emigrants. Although some of them, mostly associated with exile political structures (the best example of which is Pavel Tigrid, who became the Minister of Culture after his return), have returned to the Czech Republic, re-emigration from the West in the 1990s has been comprised mostly of the August 1968 emigrants, and even by later members of that wave.

\section{The western emigrants' return in the $1990 \mathrm{~s}$}

As mentioned above, the pilot study included 20 respondents who live in Prague or in its suburbs. The gender structure of the group ( 16 men, 4 women) corresponded to the assumed structure of emigrants [Hrubý-Brouček 2000: 28], and also reflected the higher integration of women into the host society, due to their family and social relations. In general, women usually return only in couples/families, while many male emigrants return alone or soon after a divorce. ${ }^{10}$ The former host countries of the respondents are the USA (50 per cent of cases), Great Britain (20 per cent), Australia, Spain, Sweden, Switzerland, and Germany (with a secondary migration to Austria); all of the re-emigrants were members of the August 1968 emigration wave who had been abroad for 4 to 26 years.

\footnotetext{
${ }^{9}$ In some cases an important factor is the ambivalent perception of themselves and/or the hostility of the Czech majority, along with the unhelpful attitude of the Czech government (refusal of dual citizenship till 1999, negative support for the emigrants' struggle for property restitution, etc.). Holý 1996: 66-69.

${ }^{10}$ At the time of return (or due to the impact of returning) some two-thirds of male returnees of the group were divorced. Most of them responded that searching for a new life-partner had been among their re-emigration motives ( 3 of them have already married again).
} 


\subsection{Reasons for emigration, anticipations, and host-society integration}

There were usually a variety of quite different reasons for emigration cited by the respondents; in the case of emigrants who left Czechoslovakia soon after August 1968, the reasons included religious faith, interpersonal relations ('everyone left at the same time ... and my friends needed someone who spoke English', one respondent said), but even pure individualism, which led to a strong 'Western yearning' at any cost. All these emigrants were granted political asylum within a short period of time ${ }^{11}$ and contacted existing Czech organisations in the host country. With the help of these kinds of networks (and in Europe also with the help of the executive of the host country) they acquired their first job, a place to stay, and other necessary assistance. Not wanting to be limited to these opportunities alone, the emigrants therefore tried to become independent as soon as possible, especially in the sphere of work and social relations. On the other hand, emigration usually led to a considerable decline in the emigrants' social status. An important reason for this was their education, as in contrast with the later emigrants they usually had only elementary or secondary levels of education in Czechoslovakia, which was incomparable to Western education. In addition, they did not wish to be integrated fully into the host society, and with the exception of the two above-mentioned areas, they maintained strong inter-emigrant relations, while their relationship with the February 1948 emigrants was difficult. Most of them were diligent immigrants who lived in ethnically endogamous marriages, educated their children not only in the host country values but also in the above-mentioned Czech folklore. Consequently, a significant number of the second generation returned to the Czech Republic in the 1990s or could currently be characterised as uncertain fluctuants.

Emigrants of the 1970s formed a different group. The reasons that led them to emigrate were mostly based on their disappointment with the Czech political situation, especially with the onset of 'normalisation', stagnation and even denunciation in civic activities, and widespread persecution of dissent. Unsurprisingly, this emigration wave was comprised mostly of artists, musicians and others engaged in similar professions, who were able also to later obtain positions in their professional field abroad. These were exceptional individuals, which is evident in the fact that, although at the beginning they also received help from Czech emigrant networks, they left them quite soon, and eventually acquired an above-average status. But this did not necessarily lead to their full satisfaction either. Given their exceptional characters, emigrants of this kind were not able to accept the standard values of the host country or those of the emigrant groups and they remained voluntarily alone (a situation they found themselves in both prior to emigration and after re-emigration).

The emigrants of the 1980s included the group of politically motivated migrants of the 1970s who had been unable to leave Czechoslovakia earlier. But much more often the emigrants during this period were motivated by economic reasons, or reasons of personal and professional development. A number of these emigrants had worked as programmers

\footnotetext{
${ }^{11}$ The only problem was that they usually wanted to get to the USA, which was difficult at the end of the 1960s; one respondent solved this by transitory emigration to Canada, another by marriage.
} 
or other highly educated professionals, with direct personal contacts in the West, which later helped them considerably during their integration into the host society. These emigrants had usually prepared their departure long in advance (studying the language, professional know-how, social relations etc.). But once they had crossed the border the situation was not as good as they had imagined it to be: they had to stay in refugee camps for several months or even years; nobody was waiting for them with open arms. They had to accept inferior occupations, at least temporarily, and most of them tried to change the situation as quickly as possible. In some cases they studied at universities for a second time (most of the emigrants of the 1980s were university educated). In contrast with the Czech post-war emigrants, who usually became members of the lower class, these people were pure homines novi, who integrated into the host society quickly and even acquired an above-average status. Similarly, it is of significance that most of the re-emigration in the case of this group was due to the wishes of the emigrants' employers, or in response to the opportunity to obtain an increase in earnings. The most common kind of re-emigration attitude traced among this group ${ }^{12}$ was that of the radical new-settler (with ipso facto zero concern for returning home).

\subsection{Reasons for re-emigration and anticipations}

A general overview of re-emigration is presented in Table 3, which divides the re-emigrants according to the period of their emigration.

The majority of the emigrants of the 1960s and 1970s never fully accepted the cultural values of the host societies, which contributed to their decision to return after November 1989. After crossing the border again, albeit in the opposite direction, they tried to re-establish broken social relations. This effort was usually successful only on the level of kin relations, and sometimes also with neighbours (although only a small number of reemigrants actually returned to the same place of residence), but not usually in employment-related spheres. This was due to the different historical experience of the re-emigrants and the majority of the population, and also to negative feelings felt by the majority towards re-emigrants.

In spite of the fact that they tried to assimilate into a different society, the situation of the re-emigrants who emigrated in the 1980s was quite different. They have usually become easily integrated back into the Czech society given their relatively short period of absence.

One-half of the re-emigrants in the sample had hoped for positive changes to occur in their economic and professional status as a result of their re-emigration. Most of them were indeed successful ( 70 per cent), and in several cases even far beyond their expectations. But not all the re-emigrants were so lucky: five ( 25 per cent) have felt failure as they obtained the same (only the same!) position as abroad. The re-emigrants who had expect-

\footnotetext{
${ }^{12}$ The relatively high level of their re-emigration does not deny this finding; it is due to the effect of time. As I mentioned above, in many cases also economic or work causes played an important role.
} 
Table 3. Frequency of types of reemigration behaviour among the respondents

\begin{tabular}{|l|c|c|c|c|}
\hline Type & $\begin{array}{c}\text { frequency } \\
\mathbf{1 9 6 8 - 1 9 6 9}\end{array}$ & $\begin{array}{c}\text { frequency } \\
\mathbf{1 9 7 0 - 1 9 7 9}\end{array}$ & $\begin{array}{c}\text { frequency } \\
\mathbf{1 9 8 0 - 1 9 8 9}\end{array}$ & Total \\
\hline radical new-settler & 0 & 0 & 4 & 4 \\
\hline uncertain fluctuant & 3 & 1 & 0 & 4 \\
\hline radical patriot & 1 & 0 & 0 & 1 \\
\hline diligent reemigrant & 3 & 4 & 2 & 9 \\
\hline diligent immigrant & 0 & 1 & 1 & 2 \\
\hline Total & 7 & 6 & 7 & 20 \\
\hline
\end{tabular}

ed no changes in this sphere, or who had not thought about it given that they had different reasons for returning, were positively surprised, and most of them ( 75 per cent) have found a better position, primarily owing to their knowledge of foreign languages and their professional experience. Especially right after 1989 their only advantage was their language (usually English) skills, which in many cases led to them being enviously evaluated negatively by other people. Among the re-emigrants we can find translators, physicians, musicians, ministers, and especially high-positioned bank managers, and rich entrepreneurs.

Society's adoption of the re-emigrants contrasts sharply with their prosperity. Almost nobody was interested in any deeper information on their Western economic and work know-how, and if someone were it was due to their position in the firm hierarchy. Conversely, the re-emigrants arrived with the conviction that they could become the best practitioners or even the opinion leaders in the economic sphere (and sometimes also in politics), and consequently they felt that they had been double-crossed. They had similar feelings of dissatisfaction with respect to the work ethic and the habits of their Czech partners, collaborators, and civil servants. All of them have repeatedly complained of poor work attitudes, non-observance of informal agreements, poor risk-taking abilities, and little real team work, and of deep individualism in the material sense, dysfunctional social net-working, corruption, and distrust in practically all areas. Some respondents who work in international or foreign firms believe things are improving, while those who have to collaborate with the state administration disagree. In their view, the situation is a result of the persistent influence of the communist regime on ethics. However, the re-emigrants from the USA emphasise that similar problems (though to a lesser degree) are also evident in Western Europe, typically among their Austrians partners.

Whereas many re-emigrants came to the Czech Republic with the conviction that they intended to help the country, they have not only met with a lack of interest, but also with the clearly negative reaction of the majority. Their former contacts did not help them either, with the exception of family and close friends (and sometimes also relations on a religious basis); in some cases they were even counterproductive. Above all, it was the aversion of the majority to any adjustment to Western, and especially American standards of work and economic behaviour that have led to this negativity. The only area of adjustment seen by the respondents is in the area of consumption. 
Given the limited size of the group of respondents there are some questions that could not be solved here, but I would at least like to mention that the return of some emigrants was in fact a flight from the current (Anglo)-American flexible capitalism and its negative externalities, which are described by R. Sennett [1998]. The majority of the reemigrants from the USA and the United Kingdom (57 per cent) used to work under flexible conditions. It is quite clear that for most of them their return led to a decrease in this kind of work flexibility; any other development was a consequence of their decisions usually accompanied by a considerable increase in their status. One can conclude that re-emigration was in some cases a personal defence against the new capitalism and a struggle for a better job, although these were not the only reasons for return.

Now I would like to discuss some important differences in values that exist between the re-emigrants and the Czech majority.

\subsection{Fundamental individualism vs. consumption individualism}

Clearly the most important difference in values lies in the attitudes towards relations between the individual and the collective, which affect all institutional spheres. The attitude of the re-emigrants, which has its origin in their personal experience and also in Western social values, can be called 'fundamental individualism'. It is a conviction that any social group, regardless of its size, is primarily a collection of its members, who maintain a certain kind of social behaviour. The group is characterised by this behaviour and by it alone, while this behaviour also determines the position of the person in the social hierarchy. According to this conviction, nothing comes 'for free', and everything that is done by someone else needs to be paid for. A typical example is a statement made by the singer Karel Kryl, that 'except for a scholarship, which I later paid off, I got nothing for free. I owe no [German] Mark to the German state. And I am proud of this fact'.

On the other hand, if any social behaviour is a cause of status differences, it is also their result and manifestation. As a result of this statement, which ipso facto stems from their fundamental individualism, many of the re-emigrants were accused of showing off, even though this kind of individualism certainly did not indicate a lack of interest in civic and public affairs. In fact, the very opposite was true, because as mentioned above, the majority of the re-emigrants came back with the hope of helping Czech society and they later took part in many civic and/or cultural activities. However, they wanted some 'payment' for this activity, at least in the form of social acceptance. Whereas especially the 1960s and 1970s emigrants felt a 'great, incommunicable homesickness', they felt it to be their own affair and did not expect any 'compensation'. On the other hand, they did expect positive adoption and collective work in setting up local, interest, national, etc. communities, which would lead to the benefit of everyone.

According to the re-emigrants, the perception the majority has of the relations between the individual and the collective is fundamentally different from their own. Whereas they sometimes also refer to it as 'individualistic', it is in a pejorative sense [Brouček et al. 2001: 44]. It should be called 'consumption individualism', given that those who partake 
of it endeavour to obtain the maximum from the collective for their own (or their families') consumption, and with no payment. In the words of L. Holý [1996: 24, 17-27], which describe the situation under communist rule but are still valid afterward: "charity [and moral behaviour] ... did not begin at home, it ended there". For example, the attitude of the majority to corruption can be seen as fundamentally positive according to the slogan 'all of us stole [during the communist period], so they [the new elites] may steal now'.

Consumption individualism also affects status demonstration. The Czech majority, unlike the re-emigrants, try to maintain a false egalitarian appearance, conceal their own achievements, or give the consumption free run, in the sense of Veblen's demonstrative consumption [1899: chap. 4.]. The same difference can be found also in relation to property, which is often seen by the re-emigrants as a Weberian 'calling'. For example, it is difficult for them to comprehend the lack of maintenance devoted to houses and roads during the communist era, as is the present way of dealing with some of the property returned in restitution when it is used for direct consumption, sometimes demonstratively, and with no care for the future. This way of using property seems also to influence its acquisition: "many of the Czechs whom I have to deal with in my business", says the Dutch husband of one re-emigrant, "do not have any experience with business, they just want to become rich, even through fraud ... They do not understand that a good name and reliability are the basis of business" [Brouček et al. 2001: 42].

After entering the Czech social environment, re-emigrants were usually surprised by the poor observance of informal agreements [Brouček et al. 2001: 43], and by the consequent mistrust and formalism of (mainly administrative) actions. They met with this at every step - from frequent certification of personal identity to written conclusions for all agreements and strong demands for formal work qualifications. One typical example of this behaviour is that of a university professor, a former translator of one American bestseller, who has obstructed the recent publication of its new translation, as the translator (a re-emigrant) is not a university graduate; or the case of judge E. Wagnerová, whose appointment as the Supreme Court member was obstructed by former prime minister, Václav Klaus, because she had earlier worked as a dentist for one year (!) during her emigration period [Navara-Wagnerová 2002]. In both cases, the problem was of course the interpersonal competitive fight, but even the possibility of this kind of argumentation existing is significant.

This formalism and consumption individualism, based on a collectivistic understanding of the nation [Holý 1996: 61-65], leads to a relatively low level of self-esteem among the Czechs, which is compensated through the envy directed at the re-emigrants. All of them, and especially the USA re-emigrants, think that high self-esteem is the necessary condition for success in work. 'When you do something, you do it in the best possible way. This is what I have learned in the States', says one re-emigrant, who without any former education became an art designer and later a movie director there. Usual Czech behaviour is just the opposite. 


\section{In conclusion: cultural values in the re-emigration process}

The topic of Czech (re-)emigration studies, which I have briefly introduced in this paper, would seem to be very important for sociological research; it reveals some highly interesting findings not only on the nature and reasons for migration, but also on contemporary Czech society, and its comparison with Western societies, whose (usually idealised) level of development most Czechs want to achieve. While the direct comparison is often not very convincing as it reveals rather cultural distance or even divergence, some conditional cross-country comparisons can still be quite revealing.

As discussed above, the key interpretational scheme of a value struggle between Western re-emigrants and the Czech majority, which affect all other institutional spheres, is the different concept of individualism and its relation to collective entities. While the Czech population still inclines towards the older collectivistic concept of the nation, and its relations to institutions have emerged out of consumption individualism, as a result of their Western experience the re-emigrants have come up with liberal fundamental individualism, which is eventually more beneficial. The former leads to selfishness, and to the 'to have' life-attitude of E. Fromm's concept [1976], while the latter positively changes society by changing individuals and leads to a deepening of moral dimensions (the 'to be' attitude). The emigrants' flight from flexibility can also be seen as an escape from the corrosion of their character, which can be brought about by some forms of modern capitalism. The other reasons for returning included traditional liberal values, admiration for the 'velvet revolution', and the will to participate in the structural change of Czech society, while private benefits were usually also a factor. The social attitudes of the Czech majority are in sharp contrast (to those of the re-emigrants). Although they have temporarily (and mostly only rhetorically) accepted liberal values, in fact they have preserved their consumption individualism, which respects only private, familial, or other narrow interests.

On the other hand, it is clear that the re-emigrants form only a small minority of all emigrants. While the February 1948 emigrants have for the most part not returned, given the passage of more time and the presence of established social links, a significant part of the August 1968 emigrants, who left the country for economic and professional reasons, have become the radical new-settlers in their host countries and there are no incentives for them to return. People of this kind, as well as uncertain fluctuants and diligent immigrants who feel their economic and labour dependence in the host countries, formed a large majority of this (1968) emigration wave. Only a small part have returned, and these are either the radical patriots, who ostentatively parade Czech cultural champions, or (more frequently) they are diligent re-emigrants, who carefully balance the cultural values of both societies and a real observance of these values; the people for whom their migration lifeexperience has become a real personal benefit. It is only they who can be the real contributors to Czech society as a whole, as they are able to apply their foreign experience to cultivation in the social, political, economic, cultural, and other spheres. 
ZDENĚK R. NEŠPOR graduated in the humanities and social anthropology from the Faculty of Humanities, and in history of religions from the Faculty of Arts of Charles University in Prague. At present he is a PhD. candidate in history at the Faculty of Arts. He works as a researcher in the Institute of Sociology of the Academy of Sciences of the Czech Republic and lectures at the Faculty of Humanities. His research focuses on pre-modern and modern Czech history, religious and cultural studies, and sociological and anthropological analyses of institutions. He has published approximately twenty papers.

\section{References}

Berger, Peter L., Thomas Luckmann 1966. The Social Construction of Reality: A Treatise in the Sociology of Knowledge. New York: Doubleday.

Brouček, Stanislav, Karel Hrubý, Antonín Měštan (eds.) 2001. Emigrace a exil jako způsob života. [Emigration and Exile. As a Way of Life]. Praha: Karolinum + EÚ AV ČR.

Češi v cizině 1992. Češi v cizině 6. [Czechs Abroad 6.] Praha: Ústav etnologie a folkloristiky ČSAV.

Chada, Joseph 1981. The Czechs in the United States. [Washington D.C.]: SVU Press.

Filípek, Jan 1999. Odlesky dějin československého exilu. [Reflections on the History of the Czechoslovak Exile].

Fromm, Erich 1976. To Have or To Be? New York: Harper \& Row.

Hoenekopp, Elmar 2000. "Central and Eastern Europeans in the Member Countries of the European Union since 1990: Development and Structure of Migration, Population and Employment”. In: OECD Seminar on Recent Developments in Migration and the Labour Market in Central and Eastern Europe in the Context of EU Enlargement, Bratislava 2.-3. 5. 2000. Unpublished paper, pp. 1-43.

Holm, Nils G. [1993] 1998: Úvod do psychologie náboženství. [A Prolegomena to the Psychology of Religions]. Praha: Portál.

Holý, Ladislav 1996. The Little Czech and the Great Czech Nation: National Identity and Post-Communist Social Transformation. Cambridge: Cambridge University Press.

Hrubý, Karel, Stanislav Brouček (eds.) 2000. Češi za hranicemi na prelomu 20. a 21. století. [Czechs Beyond the Borders at the Turn of the $21^{\text {st }}$ Century]. Praha: Karolinum + EÚ AV ČR.

Koudelka, František et al. 1993. Soudní perzekuce politické povahy v Československu v letech 1948-1989: Statistické údaje. [Judicial Persecutions in Czechoslovakia in 1948-1989: Statistical data]. Praha: ÚSD AV ČR.

Light, Ivan, Stavros Karageorgis 1994. "The Ethnic Economy”. Pp. 647-671 in Smelser, Neil J., Richard Swedberg (eds.). The Handbook of Economic Sociology. Princeton - New York: Princeton University Press + Russel Sage Foundation.

Navara, L., E. Wagnerová 2002. “Češi někdy až přiliš projevují závist” [Czechs Are Sometimes Too Envious; an interview]. Mladá Fronta Dnes 1. 7. 2002: C/10.

Nešpor, Zdeněk R., Martina Hornofová, Marek Jakoubek 1999-2002. "Čeští nekatolíci v rumunském Banátě a v Bulharsku I.-IV”. [Czech Non-Catholics in Romanian Banat and Bulgaria I. - IV.]. Lidé města 2/1999: 66-88, 4/2000: 112-141, 5/2001: 62-86, 6/2002 (forthcomming). 
Schütz, Alfred 1944. "The Stranger: An Essay in Social Psychology”. American Journal of Sociology 49: 499-507.

Schütz, Alfred 1945. "The Homecomer”. American Journal of Sociology 50: 369-376.

Secká, Milena 1992. "Migrace Čechů z Rumunska do České republiky (bývalé ČSFR) a vývojové aspekty jejich adaptačního procesu” [The Migration of Romanian Czechs to the Czech Republic (Former ČSFR) and Development Aspects of Their Adaptation Process]. Český lid 80, 1993, 3: 177-184.

Secká, Milena 1993. “Češi v Rumunsku” [Czechs in Romania]. Pp. 96-104 in Češi v cizině 9. Praha: Ústav etnologie a folkloristiky ČSAV.

Sennett, Richard 1998. The Corrosion of Character: The Personal Consequences of Work in the New Capitalism. New York - London: Norton.

Tigrid, Pavel [1974] 1990. Politická emigrace v atomovém věku [Political Emigration in the Atomic Era]. Praha: Prostor.

Veblen, Thorstein 1899. The Theory of the Leisure Class: An Economic Study of Institutions.

New York: Macmillan. 